\title{
The abandonment of maize landraces over the last 50 years in Morelos, Mexico: a tracing study using a multi-level perspective
}

\author{
Francis Denisse McLean-Rodríguez ${ }^{1} \cdot$ Tania Carolina Camacho-Villa $^{2} \cdot$ Conny J. M. Almekinders ${ }^{3}$ - Mario Enrico Pè ${ }^{1}$ \\ Matteo Dell'Acqua ${ }^{1}$. Denise E. Costich ${ }^{4}$
}

Accepted: 11 March 2019 / Published online: 27 March 2019

(c) The Author(s) 2019

\begin{abstract}
Understanding the causes of maize landrace loss in farmers' field is essential to design effective conservation strategies. These strategies are necessary to ensure that genetic resources are available in the future. Previous studies have shown that this loss is caused by multiple factors. In this longitudinal study, we used a collection of 93 maize landrace accessions from Morelos, Mexico, and stored at the International Maize and Wheat Improvement Center (CIMMYT) Maize Germplasm Bank, to trace back to the original 66 donor families after 50 years and explore the causes for why they abandoned or conserved their seed lots. We used an actor-centered approach, based on interviews and focus group discussions. We adopt a Multi-Level Perspective framework to examine loss as a process, accommodating multiple causes and the interactions among them. We found that the importance of maize landrace cultivation had diminished over the last 50 years in the study area. By 2017, 13 families had conserved a total of 14 seed lots directly descended from the 1967 collection. Focus group participants identified 60 accessions that could still be found in the surrounding municipalities. Our findings showed that multiple interconnected changes in maize cultivation technologies, as well as in maize markets, other crop markets, agricultural and land policies, cultural preferences, urbanization and climate change, have created an unfavorable environment for the conservation of maize landraces. Many of these processes were location- and landrace-specific, and often led to landrace abandonment during the shift from one farmer generation to the next.
\end{abstract}

Keywords In situ $\cdot$ Ex situ $\cdot$ Conservation $\cdot$ Genetic erosion $\cdot$ Plant genetic resources $\cdot$ Zea mays

\section{Abbreviations \\ CGIAR Consultative Group for International Agri- cultural Research \\ CIMMYT Centro Internacional de Mejoramiento de Maíz y Trigo (International Maize and Wheat Improvement Center)}

Electronic supplementary material The online version of this article (https://doi.org/10.1007/s10460-019-09932-3) contains supplementary material, which is available to authorized users.

Tania Carolina Camacho-Villa

C.Camacho@ cgiar.org

Francis Denisse McLean-Rodríguez

f.mcleanrodriguez@sssup.it

Conny J. M. Almekinders

conny.almekinders@wur.nl

Mario Enrico Pè

m.pe@sssup.it

Matteo Dell'Acqua

m.dellacqua@sssup.it

Denise E. Costich

D.Costich@cgiar.org
1 Institute of Life Sciences, Scuola Superiore Sant'Anna, Piazza Martiri della Libertà 33, 56127 Pisa, Italy

2 Socioeconomic Program, International Maize and Wheat Improvement Center (CIMMYT), Km. 45, Carretera México-Veracruz, 56237 Texcoco, Estado De México, Mexico

3 Knowledge, Technology and Innovation Group, Wageningen University, Hollandseweg 1, 6706 KN Wageningen, Gelderland, The Netherlands

4 Maize Germplasm Bank, Genetic Resources Program, International Maize and Wheat Improvement Center (CIMMYT), Km. 45 Carretera México-Veracruz, 56237 Texcoco, Estado De México, Mexico 
CIVAC Ciudad Industrial del Valle de Cuernavaca (Industrial City of the Cuernavaca Valley)

CONABIO Comisión Nacional para el Conocimiento y Uso de la Biodiversidad (National Commission for the Knowledge and Use of Biodiversity)

GDP Gross domestic product

INEGI Instituto Nacional de Estadística y Geografía (National Institute of Statistics and Geography)

INIA Instituto Nacional de Investigaciones Agrícolas (National Research Institute in Agriculture)

INIFAP Instituto Nacional de Investigaciones Forestales, Agrícolas y Pecuarias (National Research Institute in Forestry, Agriculture and Livestock)

MASL Meters above sea level

MLP Multi-Level perspective

PROCEDE Programa de Certificación de Derechos Ejidales y Titulación de Solares Urbanos (Certification Program for the Rights over Ejido Lands and Urban Plots)

SAGARPA Secretaría de Agricultura, Ganadería, Desarrollo Rural, Pesca y Alimentación (Secretariat of Agriculture, Livestock, Rural Development, Fisheries and Food)

SEGOB Secretaría de Gobernación (Secretariat of Government)

SPP Secretaría de Programación y Presupuesto (Secretariat of Programming and Budget)

\section{Introduction}

Ex situ and in situ conservation strategies are necessary to ensure that genetic resources are available in the future for farmers, breeders and the society at large (Harlan and Martini 1936; Frankel 1950; Frankel and Bennett 1970). Conservation in genebanks (ex situ) has been a key strategy for making accessions readily available for breeding and research; safeguarding samples of crop populations whose persistence is imminently threatened and protecting these resources from unpredictable crises or natural disasters in the field. ${ }^{1}$ Complementarily, conserving landrace populations in farmers' fields (in situ) ensures that new genetic diversity is generated and, in turn, that natural and farmers'

\footnotetext{
${ }^{1}$ An item added to an existing collection. Here used to refer to any item stored in a genebank collection, including the seeds and all their associated data.
}

selection act upon this diversity. ${ }^{2}$ This is especially important in the centers of origin and diversification of crops, as continuous selection allows landraces to adapt to climate change, biotic and abiotic stresses, farmers' practices and users' preferences. Advances in pre-breeding and molecular technologies are facilitating the identification of the genetic basis of useful traits in landraces and their incorporation into breeding pipelines (Dwivedi et al. 2016). Moreover, the conservation of landraces in farmers' fields supports farmers' rights to save and exchange germplasm and strengthens the role of developing countries in the conservation of global genetic resources (Brush 1995).

To design effective conservation strategies it is essential to understand the causes for the conservation as well as for the abandonment of landraces in farmers' fields. For maize in Mexico, the factors associated with in situ conservation have been extensively researched. Documented evidence linked conservation to farmers' management of heterogeneous environments, soils, pests, pathogens and climate risk (Ortega-Paczka 1973; Bellon 1991, 1996; Bellon and Taylor 1993; Bellon and Brush 1994; Fenzi et al. 2015), farmers' ethnicity (Brush and Perales 2007), use and consumption preferences (Perales et al. 2003a; Bellon and Hellin 2011), and farm scale (Keleman et al. 2013). These findings have been used to design conservation interventions (Bellon 2004) and to identify the most promising areas for their costeffective implementation (Smale et al. 2004). In contrast, the causes of landrace abandonment have been less explored.

Few studies have examined the causes for maize landrace loss empirically. For example, Rice (2007) found that the reasons farmers had to abandon the Jala landrace in Nayarit, Mexico were related to the agronomic superiority of hybrids, to the demand for high yielding, dense, white grain and to the development of a specialized market for husk leaves for tamale wrapping, for which the Jala landrace was not considered suitable. In the region surrounding Lake Pátzcuaro, in the Mexican state of Michoacán, Astier et al. (2012) found that unfair market competition, food system transformations towards manufactured products, and the introduction of commercial crops threatened the continued cultivation of landraces in traditional agro-ecosystems. Wale (2012) identified that the main reason for farmers to abandon landraces, including maize, in Ethiopia was that the productivity of landraces has been deteriorating with time.

Many authors argued that landrace loss is the result of multiple processes, including population growth, poverty,

\footnotetext{
${ }^{2}$ Landraces are defined as: "dynamic population(s) of cultivated plants with a historical origin, distinct identity and lacking formal crop improvement, as well as often being genetically diverse, locally adapted and associated with traditional farming systems" (CamachoVilla et al. 2005). They are alternatively known as traditional, folk, local or native varieties in literature.
} 
markets, and cultural change (Brush 2004). Likewise, urbanization, land use change, agricultural modernization, changes in food preferences, climate change, environmental degradation, as well as natural and human disasters, are among the latent causes of crop genetic erosion (van de Wouw et al. 2009). For maize in Mexico, socioeconomic changes such as migration, integration into the non-farm economy and decreasing attractiveness of farming could decrease farmers' interest in landrace diversity maintenance (Bellon 2004). Maize landraces may as well be threatened by industrialized flour subsidies that favor maize hybrids, and by the substitution of maize with other crops (OrtegaPaczka 2003). However, these observations come from studies focused on conservation. A focus on the process of maize landrace abandonment, acknowledging the interconnected nature of the multiple causes of loss, is still needed.

To review the process of maize landrace abandonment over the longest possible period of time we designed a longitudinal study. We reviewed the passport information of accessions from the International Maize and Wheat Improvement Center (CIMMYT) Maize Germplasm Bank, and found a unique collection from 1966/1967. The collection's field report contained enough information to trace back to the farmers who donated the seeds. Fifty years later, we revisited the original farmer-donor families and empirically documented the factors that led them to abandon or conserve their maize landrace seed lots. ${ }^{3}$ Because crop genetic erosion is a meta-population process (van Heerwaarden et al. 2010; Brush et al. 2015), we compared abandonment on two levels: among the families, as well as among the municipalities where the families reside.

We analyzed farmers' explanations for abandoning their seed lots from an integrated actor-centered framework called the Multi-Level Perspective (MLP) (Geels 2004). The MLP originated in the field of Innovation Studies. It has been used to analyze the possibilities, barriers, and drivers of largescale technological transitions in the context of sustainable development; for example, in the transportation, electricity, organic food and sustainable housing sectors (Geels 2005; Smith 2007; Verbong and Geels 2007). The MLP provides a framework for analyzing multiple causes together and emphasizes how they influence each other. We report how these causes, which are often location- and landrace-specific, have created an unfavorable environment for the conservation of maize landraces in the study area. We then discuss how this understanding could be used to support maize landrace conservation efforts.

\footnotetext{
${ }^{3}$ Seed lots are all of the seeds of a given crop cultivar selected by a farmer and planted throughout a specific cultivation cycle, as well as the direct descendants of these seeds (Louette 1994). Thus, seed lots are the objective units of farmers' management.
}

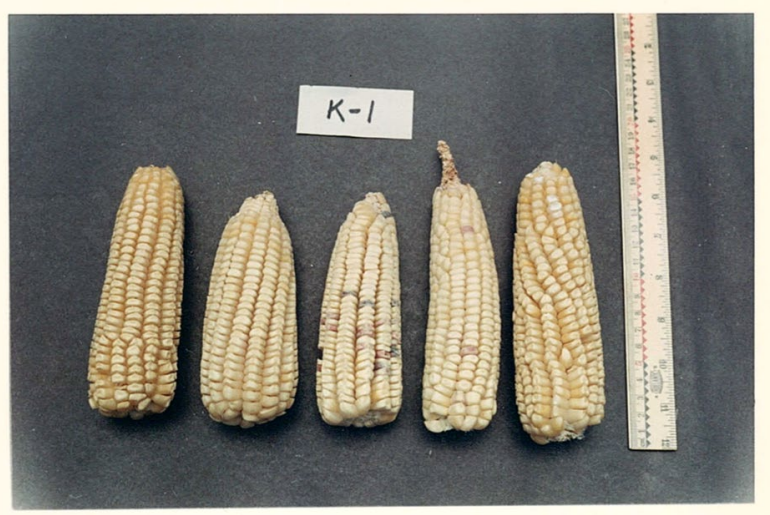

Fig. 1 Example of an original photograph of representative ears of a 1967 collection accession (Kato 1967)

\section{Data collection and analysis}

From the CIMMYT Germplasm Bank, we selected a set of 93 accessions obtained from 66 families in Morelos. Dr. Ángel Kato, the collector and a research assistant in the Bank at the time, compiled detailed information for this collection. For each accession, Dr. Kato registered the name of the farmer-donor, the location where the accession was collected, the common name of the landrace, the number of collected ears and a photograph of the representative ears (Kato 1967) (Fig. 1). With this information, we were able to trace back to the same families in 2016/2017, 50 years after the collection took place.

The choice of this collection determined our geographic area of study. Accessions came from 19 of the 33 municipalities of Morelos (Fig. 2). The area was, and still is, known for the cultivation of the Ancho landrace. Because Ancho was not considered a distinctive race at the time, the collector's aim was to obtain more Ancho accessions for cytogenetic characterization. ${ }^{4}$ As a result, almost half of the collection was comprised of Ancho accessions, but the collection also included other landraces cultivated in the area.

With $4958 \mathrm{~km}^{2}$ in area, Morelos is the second smallest state of Mexico. Elevation in the area ranges between 940 and $4460 \mathrm{~m}$ above sea level (masl). From north to south, the

\footnotetext{
${ }^{4}$ Races are defined as: "groups of related individuals with enough characteristics in common to permit their recognition as a group. [...] From the standpoint of genetics a race is a group of individuals with a significant number of genes in common" (Anderson and Cutler 1942). Wellhausen et al. (1951) formalized the basis of the current maize racial classification system. In Mexico, "race" and "landrace" are not interchangeable terms: All landraces can be classified into races, while some races include both landraces and improved varieties (Perales and Golicher 2014).
} 
Fig. 2 Geographical distribution of the 93 accessions collected in 1967 in the state of Morelos, Mexico (Kato 1967)

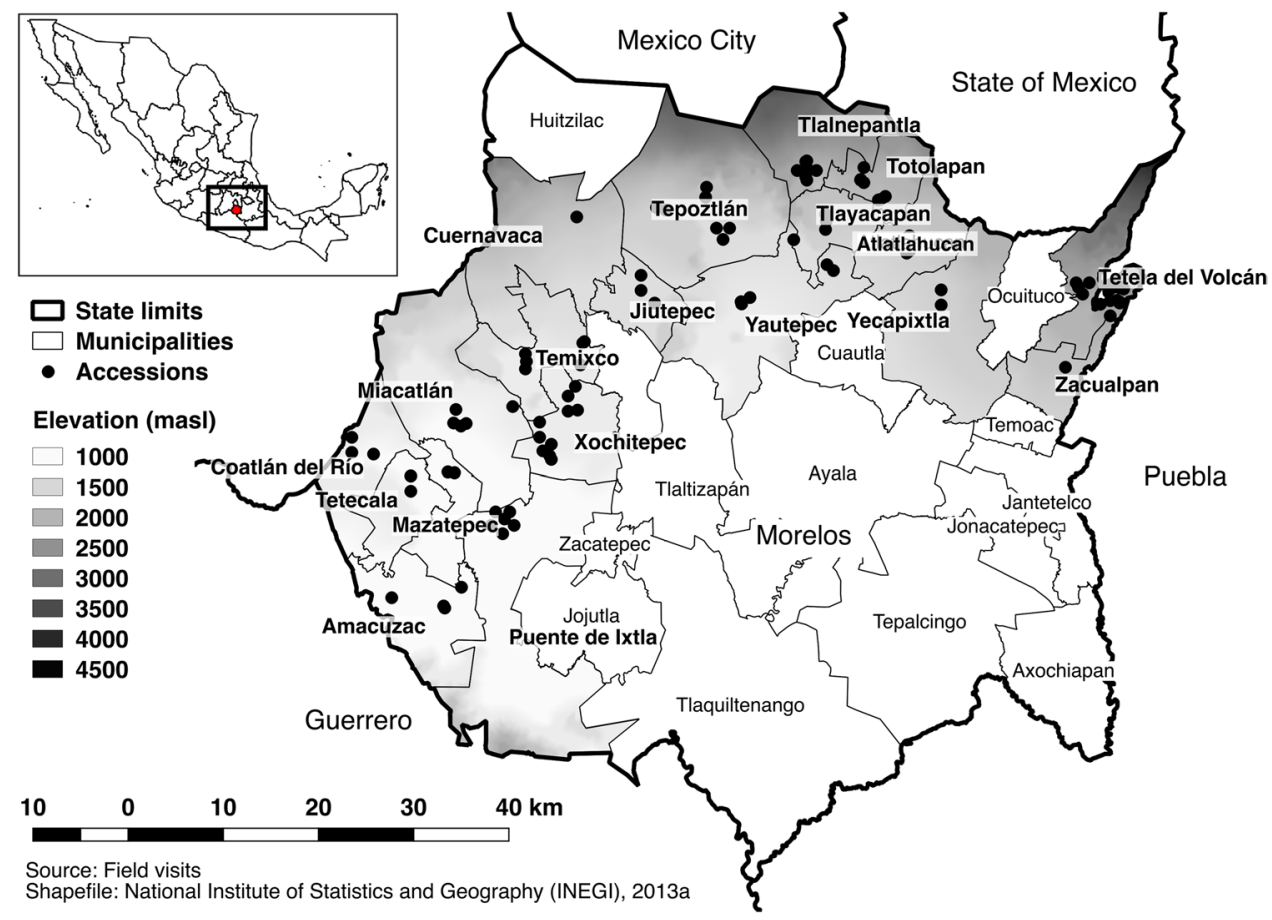

area encompasses five climates: semi-cold humid, semi-cold sub-humid, temperate sub-humid, semi-warm sub-humid and warm sub-humid (INEGI 2017). Average annual temperature varies from $17{ }^{\circ} \mathrm{C}$ in the highlands to $24^{\circ} \mathrm{C}$ in the lowlands. Average annual precipitation varies from $870 \mathrm{~mm} /$ year in the lowlands to $1070 \mathrm{~mm} /$ year in the highlands. In all municipalities, most rainfall is concentrated between July and September.

The proximity to Mexico City has boosted Morelos' commerce and services. The state capital Cuernavaca is located less than $100 \mathrm{~km}$ from Mexico City. Primary, secondary and tertiary sector GDP shares transformed from $21 \%, 26 \%$ and $53 \%$ respectively in 1970 to $3 \%, 30 \%$ and 67\% in 2014 (Ávila Sánchez 2001; INEGI 2016). Between 1970 and 2010, Morelos' population increased by a factor of 1.8, a factor larger than that for the whole country (1.3). Meanwhile, the urban population share increased from 37 to 84\% (Barseló Oliete 1982; INEGI 2014). Since the 1960s, Morelos' state government created spaces and tax incentives to attract manufacturing companies. In the 1960s, pharmaceutical and automotive industries relocated from the State of Mexico to the CIVAC industrial park in Cuernavaca Valley. This created a metropolitan area extending to the municipalities of Emiliano Zapata, Temixco, Xochitepec and Jiutepec (Ávila Sánchez 2001). Urbanization has also expanded around the municipalities of Cuautla and Jojutla.

Morelos represented an interesting case to study maize landrace abandonment and conservation for two additional reasons. First, the state is well integrated into the national economy and under the area of influence of major agricultural research centers, yet previous studies in the area found that farmers continue to cultivate, dynamically manage, and economically benefit from maize landraces (Perales et al. 1998, 2003a, b). Second, in recent years the state government demonstrated interest in maize landrace conservation, enacting a law and corresponding regulations to protect and conserve maize genetic resources (Consejería Jurídica del Poder Ejecutivo del Estado de Morelos 2014; Consejería Jurídica del Poder Ejecutivo del Estado de Morelos 2015). Morelos is one of the three Mexican states with such a law, along with Michoacán and Tlaxcala.

The first part of the study, carried out during the spring of 2016, involved semi-structured interviews with descendants of the farmers who donated the accessions to the Bank in 1967. Municipal authorities, land authorities and elderly neighbors helped us locate the families in each town based on the farmers' first and last names registered with the accessions. We interviewed the closest relatives of the farmerdonors most experienced with maize cultivation. Most frequently, interviewees were the farmers' sons or daughters, although in other cases they were the farmers' grandchildren, siblings, nephews or widows. In six occasions, we were able to interview the original farmer himself. Using the ear photographs as references, we asked interviewees what happened to their seed lot(s) after 1967 (Online Resource 1). We asked farmers to explain whether they had continued cultivating the seed lot or if they had replaced it with another seed lot of the same landrace, a seed lot from a different landrace, or an improved maize variety, or if they had transitioned to other crops or other economic activities. We then 
asked interviewees to explain the causes for any reported changes.

For the second part of the study, during the spring of 2017, we organized focus group discussions with other farmers in each of the 19 municipalities where the interviewed families lived (Online Resource 2). The focus groups had three objectives. First, because the 1967 collection targeted Ancho maize, we wanted to verify how common other landraces represented in the collection had been in the municipalities. Second, we wanted to identify if some of the landraces that had been lost in the families had been conserved at a larger scale (i.e., within the municipality). Third, we wanted to complement the experiences of the interviewed donor families with other farmers' perspectives on the causes for maize landrace abandonment in their locations. For each focus group we invited four to five farmers native to the municipality, unrelated to the donor families, experienced in the cultivation of maize landraces and, if possible, more than 70 years old.

In each meeting we analyzed the past and present occurrences of landraces using participatory methods (Grum et al. 2008, Online Resource 3). Based on the photographs of the accessions collected in each municipality in 1967, participants listed all other landraces that they recalled were cultivated at the time. Then participants listed all landraces and improved varieties currently cultivated and identified synonyms in both lists. Each item was then classified as cultivated by a few or many farmers and in small or large areas. Finally, we discussed why the occurrence of certain landraces had changed during the period and the causes for why some landraces had disappeared while other landraces and varieties had appeared in the municipalities.

\section{Analytical framework}

We adapted the Multi-Level Perspective (MLP) framework to examine maize landrace loss as a process affected by multiple causes and the interactions among them in a co-evolutionary and systemic way (Geels 2012). The MLP considers changes from one technology to another as transitions driven by multiple coevolving factors rather than by a single deliberate cause (Geels 2004). This means that a technology (like a maize landrace) is dominant in a territory because it has an enabling environment that favors its use. Changes in this environment that favor a new technology (such as hybrids or other crops) create the conditions for the replacement or displacement and concomitant loss of a particular landrace or landraces in general (the old technology).

The MLP framework considers that changes happen at different levels: from micro to meso to macro levels (Geels 2002). In this paper, we use the meso and macro levels to explain maize landrace loss. The meso level refers to the socio-technical configuration that creates a disenabling environment for landraces. This refers to the research that generates improved materials or the technological packages for new crops that will replace landraces. Similarly, it involves the input markets that supply the technology, as well as the grain markets that demand new specific qualities, decreasing the comparative advantage of landraces. It also includes the infrastructure that supports these markets and the policies and institutions that regulate technology supply and use. Additionally, the meso level refers to the users' practices and cultural preferences and values (i.e., how a maize variety is used, its value and why it is preferred). Within the MLP, these elements are called, correspondingly, the technological, scientific, market, infrastructure, policy and cultural regimes. At the macro level, the enabling environment encompasses forces such as changes in the climate, economy and population trends. ${ }^{5}$ These forces are beyond the control of any individual actor in the regimes, including researchers, companies, traders, politicians, farmers, and consumers, both urban and rural.

With this framework, loss is understood as a process of systemic changes because changes in one part of the system can foster or reinforce changes in another part of the system. For example, a subsidy can encourage markets to supply more of a given technology; a new road can connect other users to the markets; a change in climate might require different farmers' practices; or increasing urban populations might demand novel regulations. Eventually, meso- and macro-level changes can accumulate, creating a new environment that leads to landrace replacement or displacement. Because a new enabling environment favors a new dominant technology (like hybrids or alternative crops), several mesoand macro-level changes would also be necessary to achieve landrace conservation goals.

We used the MLP to position maize landrace cultivation in the area of study and show how it has been both subject to, and the result of, multiple changes in time. We interpreted farmers' explanations of the important processes that led to landrace abandonment since 1967 as changes in the MLP levels. Farmers' explanations were classified into categories corresponding to the technological, scientific, market, infrastructure, policy and cultural regimes (meso level), or factors beyond actors' control (macro level). Within these categories, we distinguished between changes that affected the preference for maize and changes that affected the preference for maize landraces. We then described results in a sequence that illustrated how different causes were interconnected.

\footnotetext{
5 Within the MLP these forces are called the "landscape" (Geels 2002), but we use the term "macro-level" for clarity. See discussion in Urquijo and Bocco (2011).
} 
Table 1 Family activities in relation to maize cultivation in 2017

\begin{tabular}{lrr}
\hline Activity & $\begin{array}{l}\text { Number of } \\
\text { families }\end{array}$ \\
\hline Unknown (family not found) & 10 & $15 \%$ \\
No longer involved in agriculture & 16 & $24 \%$ \\
Cultivating crops other than maize exclusively & 7 & $11 \%$ \\
Cultivating hybrid maize only, among other crops & 11 & $17 \%$ \\
Cultivating both hybrids and maize landraces, among & 3 & $4 \%$ \\
$\quad$ other crops & 19 & $29 \%$ \\
Cultivating maize landraces only, among other crops & 66 & $100 \%$ \\
Total & &
\end{tabular}

When necessary, we contextualized farmers' explanations with statistics from the literature.

\section{Results}

\section{Reduction of the cultivation of maize landraces in the families and municipalities}

Based on the 56 interviews we were able to complete (10 of the original 66 families were not found), it was evident that the importance of maize cultivation in general had diminished over the last 50 years among the families who donated seed to the Bank in 1967. Among the interviewed families, $50 \%$ were still cultivating maize among their crops, $11 \%$ were exclusively cultivating other crops and $24 \%$ of them were no longer involved in agriculture (Table 1).
The importance of landrace cultivation, in particular, had diminished even further among the families. In 2017, $67 \%$ of the families who were still cultivating maize (33\% of the total) were growing landraces. This reduction coincided with the introduction of improved maize varieties, which farmers refer to as hybrids. Hybrids, which were not present among the families in 1967, were since adopted by $42 \%$ of the families still cultivating maize in 2017 (21\% of the total). The coexistence of hybrids and landraces in a family farm was uncommon, reported only in $4 \%$ percent of the interviewed families.

The 22 families who were still cultivating landraces in 2017 fell into three categories: (1) those who had conserved the same seed lot they donated to the Bank in 1967 under constant cultivation during the 50-year period (13 families); (2) those who had conserved the same landrace they donated to the Bank in 1967 but from a different seed lot obtained from a family member, a neighbor or from the market (five families); and (3) those who had lost the seed lot from 1967 and later introduced a seed lot of a different landrace (four families). Families in the first category conserved 14 of the 93 accessions collected in 1967, while families in the second category conserved six accessions. Together, these families had conserved $15 \%$ of the collection's accessions of the same seed lot and $22 \%$ of the same landrace (Table 2; Fig. 3). These data indicate that the families were still conserving only a small portion of the diversity present in the 1967 collection. Additionally, families in the three categories had introduced 13 landrace seed lots that were not present in 1967.

Table 2 Race and common name composition of the ex situ collection and accessions found in situ in 2017

\begin{tabular}{|c|c|c|c|c|c|c|c|c|c|}
\hline \multirow{4}{*}{$\begin{array}{l}\text { Race } \\
\\
\text { Ancho }\end{array}$} & \multirow{4}{*}{$\begin{array}{l}\text { Common names } \\
\text { Ancho (39), Ancho Negro (1), Criollo (1) }\end{array}$} & \multirow{3}{*}{\multicolumn{2}{|c|}{1967}} & \multicolumn{6}{|c|}{2017} \\
\hline & & & & \multirow{2}{*}{\multicolumn{2}{|c|}{$\begin{array}{l}\text { Same seed } \\
\text { lot }\end{array}$}} & \multicolumn{4}{|c|}{ Different seed lot } \\
\hline & & & & & & \multicolumn{2}{|c|}{$\begin{array}{l}\text { In fami- } \\
\text { lies }\end{array}$} & \multicolumn{2}{|c|}{$\begin{array}{l}\text { In } \\
\text { munici- } \\
\text { palities }\end{array}$} \\
\hline & & 41 & $100 \%$ & 7 & $17 \%$ & 5 & $12 \%$ & 31 & $76 \%$ \\
\hline Pepitilla & Delgado (16), Criollo (3), Ancho (1), Blanco (1), Lengua de Pájaro (1) & 22 & $100 \%$ & 2 & $9 \%$ & - & - & 8 & $36 \%$ \\
\hline Vandeño & Ancho (4), Tehuacán (3), Ancho De Color (1), Grueso Blanco (1) & 9 & $100 \%$ & 1 & $11 \%$ & - & - & 2 & $22 \%$ \\
\hline Chalqueño & Criollo (5), Amarillo (1), Del Monte (1), Itzihuine Amarillo (1) & 8 & $100 \%$ & 2 & $25 \%$ & - & - & 7 & $88 \%$ \\
\hline Elotes Cónicos & Negro (2), Ancho Negro (1), Criollo Negro (1), Negro o Pinto (1) & 5 & $100 \%$ & 1 & $20 \%$ & 1 & $20 \%$ & 5 & $100 \%$ \\
\hline Cónico & Del Monte (2), Rápido o Cuarenteño (1), Delgado (1) & 4 & $100 \%$ & 1 & $25 \%$ & - & - & 3 & $75 \%$ \\
\hline Elotes Occidentales & Colorado (1), Grueso Colorado (1), Grueso Negro (1) & 3 & $100 \%$ & - & - & - & - & 3 & $100 \%$ \\
\hline Olotillo & Negro (1) & 1 & $100 \%$ & - & - & - & - & 1 & $100 \%$ \\
\hline Total & & 93 & $100 \%$ & 14 & $15 \%$ & 6 & $6 \%$ & 60 & $65 \%$ \\
\hline
\end{tabular}

Number of accessions of each common name provided in parentheses. Row percentages indicate the share of ex situ accessions conserved in situ at each level per race. Racial classification reviewed by Dr. Rafael Ortega-Pazcka in 2013, using the photographs of each accession. Common names from CIMMYT Maize Germplasm Bank. "In families" refers to semi-structured interviews, and "In municipalities" refers to focus groups 
Fig. 3 Locations of the 93 accessions from the 1967 collection (Kato 1967), and in situ in 2017. Note Locations of the interviewed families are depicted on the map with shadings reporting in situ presence/ absence in 2017 and symbols reporting accessions' races, according to the legend

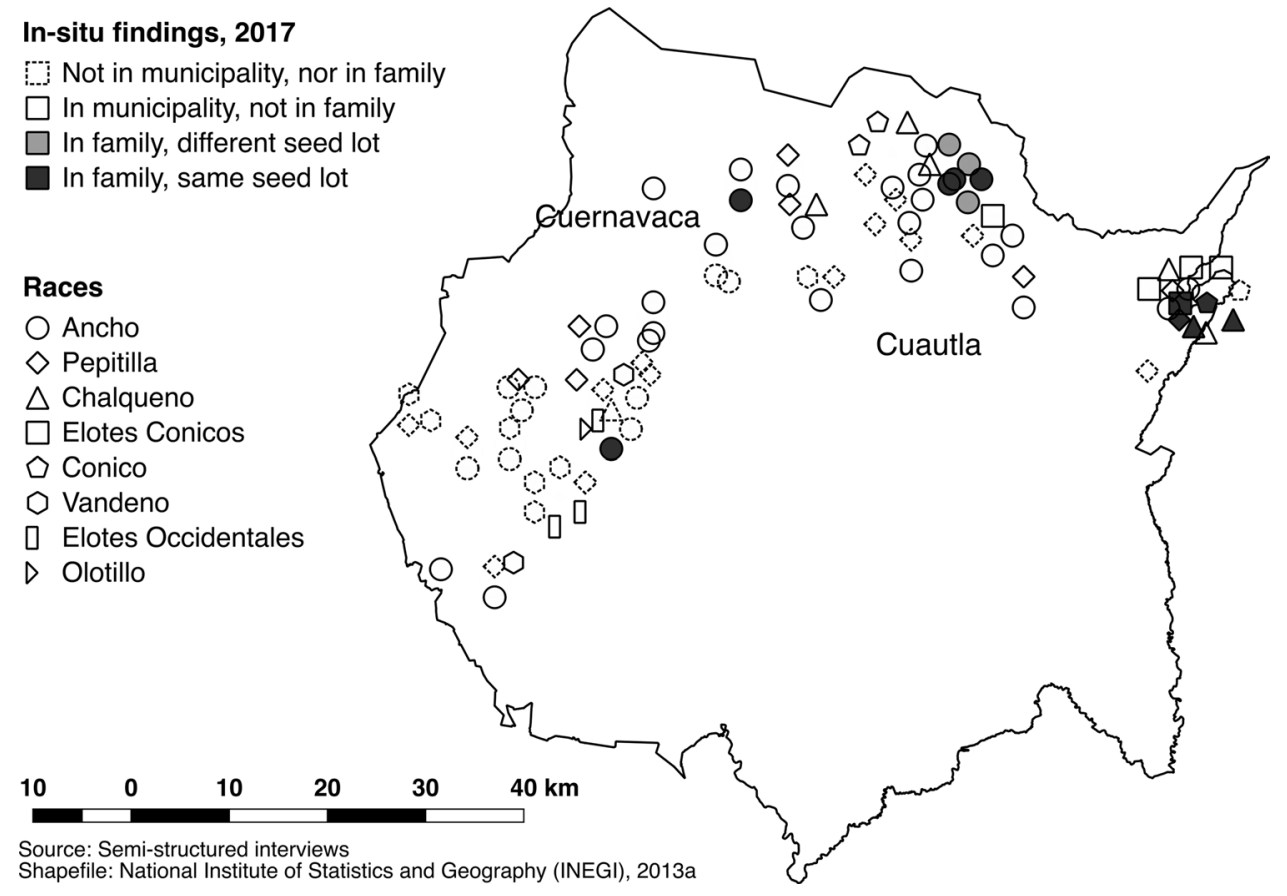

Focus group discussions included a total of 103 participants. Between three and ten farmers attended each meeting. Participants' ages ranged between 33 and 86 years old, averaging 65 years old. Farmers had between 4 and 72 years of farming experience ( 44 years on average) and between 2 and 72 years of maize landrace cultivation experience (41 years on average).

Data gathered from the focus groups suggested that the changes in presence/absence and diversity of landraces in the municipalities (meta-population level) were less pronounced than those in the families, but followed similar trends. Based on the photographs of the 1967 collections, participants identified 60 accessions that could still be found in the corresponding municipalities. Thus, the municipalities had conserved $65 \%$ of the collection's accessions of the same landrace (Table 2). Seventeen accessions overlapped with those conserved by families from the first two categories described above, but 43 accessions had only been conserved at the municipality level. The remaining 30 accessions had been abandoned, both by the families and in the municipalities.

Regardless of the presence/absence of the targeted accessions, farmers reported that the predominant trend for all landraces in their municipalities was towards a reduction in their cultivation (Table 3). Although they were present, most landraces were being cultivated by fewer farmers and in smaller areas in the municipalities. Moreover, most landraces were present in fewer municipalities, and some landraces, such as Cuarenteño and Itzihuine, had disappeared from the study area. Only the cultivation of Ancho, Negro, Arrocillo and
Criollo increased in one or more municipalities. Meanwhile hybrids, which farmers did not recall being present around 1967, had become widespread.

We determined that the occurrences of the different landraces in the 1967 collection matched the occurrences that the farmers recalled in the municipalities at the time (Table 3). Among the most common landraces, Ancho was widespread in 13 municipalities and Pepitilla in ten, planted by many farmers in large areas. The colored landraces (Negro, black maize; Azul, blue maize; Rojo or Colorado, red maize) were present in several municipalities and were planted by many farmers, but in small areas. Criollo and Del Monte were present in just a few municipalities, but planted by many farmers in large areas.

The relative occurrence of different landraces changed over time, as it was not the same in the 1967 collection as in the seed lots from the collection conserved in the families and municipalities (Table 2). Ancho remained the most common landrace, but the occurrence of Delgado decreased in situ. Other landraces such as Negro and Colorado, less abundant in 1967, were better represented in 2017. A similar trend was observed for these landraces in the discussion with focus group participants (Table 3).

\section{A multilevel perspective on why farmers reduced the cultivation of maize landraces}

\section{Radical innovation: the introduction of maize hybrids}

Maize breeders and farmers in the USA introduced hybrids in the 1930s as an alternative technology to 
Table 3 Landraces recalled by focus group participants as being cultivated in their municipalities

\begin{tabular}{|c|c|c|c|c|c|c|c|c|c|c|}
\hline \multirow{3}{*}{$\begin{array}{l}\text { Common names } \\
\text { Landraces }\end{array}$} & \multicolumn{4}{|c|}{$\begin{array}{l}\text { Number of municipalities } \\
\text { each landrace was present }\end{array}$} & \multicolumn{6}{|c|}{$\begin{array}{l}\text { Number of municipalities by predomi- } \\
\text { nant trend in landrace cultivation by } \\
2017 \text { compared to } 1967\end{array}$} \\
\hline & \multicolumn{2}{|c|}{1967} & \multicolumn{2}{|c|}{2017} & \multicolumn{2}{|c|}{ Reduction } & \multicolumn{2}{|c|}{ Increase } & \multicolumn{2}{|c|}{$\begin{array}{l}\text { Mainte- } \\
\text { nance }\end{array}$} \\
\hline & $\mathrm{n}$ & $\%$ & $\mathrm{n}$ & $\%$ & $\mathrm{n}$ & $\%$ & $\mathrm{n}$ & $\%$ & $\mathrm{n}$ & $\%$ \\
\hline Ancho, Grueso & 19 & 100 & 11 & 58 & 13 & 68 & 2 & 11 & 4 & 21 \\
\hline Delgado, Pepitilla, Lengua de Pájaro & 19 & 100 & 5 & 26 & 18 & 95 & 0 & 0 & 1 & 5 \\
\hline Negro, Azul, Ancho Negro & 18 & 100 & 17 & 94 & 11 & 61 & 2 & 11 & 5 & 28 \\
\hline Rojo, Colorado, Ancho Colorado & 10 & 100 & 8 & 73 & 5 & 50 & 0 & 0 & 5 & 50 \\
\hline Tehuacán & 8 & 100 & 3 & 38 & 11 & 138 & 0 & 0 & 1 & 13 \\
\hline Amarillo, Amarillo Criollo & 4 & 100 & 2 & 50 & 3 & 75 & 0 & 0 & 1 & 25 \\
\hline Cuarenteño & 4 & 100 & 0 & 0 & 4 & 100 & 0 & 0 & 0 & 0 \\
\hline Arrocillo & 4 & 100 & 1 & 25 & 3 & 75 & 1 & 25 & 0 & 0 \\
\hline Criollo & 2 & 100 & 3 & $>50$ & 1 & 50 & 1 & 50 & 1 & 50 \\
\hline Itzihuine & 2 & 100 & 0 & 0 & 2 & 100 & 0 & 0 & 0 & 0 \\
\hline Del Monte & 1 & 100 & 1 & 100 & 1 & 100 & 0 & 0 & 0 & 0 \\
\hline Others landraces & 5 & 100 & 3 & 60 & 4 & 80 & 0 & 0 & 1 & 20 \\
\hline Hybrids & 0 & 100 & 19 & & NA & & 19 & & NA & \\
\hline
\end{tabular}

Row percentages use the figures from 1967 as the baseline. Trends referred to the number of farmers cultivating the landraces and/or the extension of the cultivated area. Other landraces: Cacahuacintle, Ciplinado, Cuyul, Hoja Morada, Oloche, Rosa, Tepalcingueño, Tlacotero, Tremesino landraces, starting what eventually became the Green Revolution (Duvick 1996; Pistorius 1997). Their Mexican counterparts soon followed. At the time, the advantages of this new technology were based on two principles: the selection and fixation of qualitative traits and the manipulation of hybrid vigor. Breeding for qualitative traits relied on well-understood Mendelian inheritance principles. Pest and disease resistance were the best candidates among these traits, ranking high among farmers' concerns. Hybrid vigor allowed breeders to improve yield, a complex quantitative trait that would have otherwise been difficult to steadily improve.

Among the surveyed farmers, the adoption of hybrids was the principal cause for landrace abandonment, and it was mentioned 18 times in focus groups and 11 times in the interviews (Table 4). Indeed, hybrids addressed some of the common issues farmers dealt with during maize cultivation. In farmers' words, they preferred hybrids over landraces because of their higher yield by weight, shorter stature, lower incidence of lodging, greater resistance to pests and diseases, and to a lesser extent, the ability of hybrids to produce two cobs or tolerate higher planting densities. Nonetheless, farmers disliked the need to purchase hybrid seed every planting season and the considerable price they had to pay for the seed.

\section{Changes in the maize cultivation regime}

Agricultural extension service recommendations were transformed substantially with the introduction of maize hybrids, which we interpreted as a change in the scientific regime. These recommendations changed based on assessments undertaken by the National Agricultural Research Institute (INIFAP) in its experimental station in the municipality of Zacatepec, Morelos. Every year INIFAP evaluates hybrids and improved varieties for two of the agroecological zones in Morelos, dry tropical and sub-humid sub-tropical. Highest yielding cultivars are included in their maize cultivation guidelines. The cultivation system recommended for hybrids differed from that of the landraces. Farmers traditionally sowed landraces using three to five seeds per hole, leaving $1 \mathrm{~m}$ between holes. They applied natural fertilizers and controlled weeds mechanically using hand tools or animal traction. Instead, the technological package promoted during the Green Revolution included synthetic fertilizers, insecticides, herbicides and machinery, as well as improved seeds (Pichardo González 2006). INIFAP guidelines recommended higher planting densities for hybrids. Such densities increased from two seeds per hole every $50 \mathrm{~cm}$ in 1975 to a single seed every $17 \mathrm{~cm}$ in 2017 (INIA 1975; INIFAP 2017). 
Table 4 Farmers' explanation of why they reduced the cultivation of landraces, grouped by regime and macro-level categories from the Multilevel Perspective

\begin{tabular}{|c|c|c|c|c|c|c|}
\hline \multicolumn{2}{|c|}{ Changes in multilevel perspective } & \multirow[t]{2}{*}{ Farmers' explanations } & \multicolumn{2}{|c|}{ Focus groups (19) } & \multicolumn{2}{|c|}{ Interviews (56) } \\
\hline & & & Freq. & Landraces & Freq. & Landraces \\
\hline \multirow[t]{6}{*}{ Technological regime } & Affecting landraces & $\begin{array}{l}\text { Farmers preferred hybrids } \\
\text { for their: }\end{array}$ & & & & \\
\hline & & -Yield by grain weight & 9 & an, am, ar, cu, d, i, n, ro, t & 6 & an, $\mathrm{d}, \mathrm{t}$ \\
\hline & & -Lodging resistance & 6 & an, am, ar, d, n, t & 3 & an, $d$ \\
\hline & & $\begin{array}{l}\text { - Resistance to grain pests } \\
\text { and diseases }\end{array}$ & 3 & an, $\mathrm{cu}, \mathrm{d}, \mathrm{i}, \mathrm{n}, \mathrm{t}$ & - & - \\
\hline & & -Ability to produce two cobs & - & - & 1 & an \\
\hline & & $\begin{array}{l}\text {-Ability to tolerate high } \\
\text { population densities }\end{array}$ & - & - & 1 & an \\
\hline \multirow[t]{2}{*}{ Scientific regime } & Affecting landraces & $\begin{array}{l}\text { Landraces were incompatible } \\
\text { with hybrids' cultivation } \\
\text { system }\end{array}$ & 3 & an, am, ar, cu, d, n, ro, t & - & - \\
\hline & & $\begin{array}{l}\text { Farmers observed that land } \\
\text { fertility deteriorated, prefer- } \\
\text { ring hybrids }\end{array}$ & 1 & $\mathrm{am}, \mathrm{n}$ & 3 & an \\
\hline \multirow[t]{17}{*}{ Market regime } & Affecting landraces & $\begin{array}{l}\text { Farmers preferred hybrids } \\
\text { within a market oriented } \\
\text { system }\end{array}$ & 4 & an, ar, cu, d, i, n, ro, t & 2 & an, $d$ \\
\hline & & $\begin{array}{l}\text { Tortilla producers preferred } \\
\text { hybrids (also Technological } \\
\text { regime) }\end{array}$ & 4 & an, ar, d, dm, n, ro, t & 3 & an, $d$ \\
\hline & & $\begin{array}{l}\text { Farmers preferred buying tor- } \\
\text { tillas to planting maize or to } \\
\text { making tortillas }\end{array}$ & - & - & 1 & an \\
\hline & & $\begin{array}{l}\text { Landraces could not compete } \\
\text { with hybrids' higher yield } \\
\text { and lower price }\end{array}$ & 2 & $\mathrm{n}, \mathrm{t}$ & 4 & an, $\mathrm{cr}, \mathrm{n}$ \\
\hline & & $\begin{array}{l}\text { Landraces could not compete } \\
\text { with maize from other } \\
\text { states }\end{array}$ & 1 & an, am, ar, cu, d, t & - & - \\
\hline & & $\begin{array}{l}\text { Farmers preferred hybrid } \\
\text { fresh corn-on-the-cob }\end{array}$ & 3 & an, $\mathrm{d}, \mathrm{t}$ & 2 & an \\
\hline & $\begin{array}{l}\text { Affecting preference for } \\
\text { specific landraces }\end{array}$ & $\begin{array}{l}\text { Farmers preferred the Ancho } \\
\text { landrace }\end{array}$ & 3 & $\mathrm{am}, \mathrm{d}, \mathrm{n}, \mathrm{t}$ & 6 & $\mathrm{cr}, \mathrm{cu}, \mathrm{d}, \mathrm{dm}, \mathrm{n}$ \\
\hline & & $\begin{array}{l}\text { Black and red landrace was } \\
\text { disliked in public mills }\end{array}$ & 1 & $\mathrm{n}$, ro & 1 & $\mathrm{n}$ \\
\hline & & $\begin{array}{l}\text { Black and red landrace would } \\
\text { cross with white maize } \\
\text { when planted too close }\end{array}$ & - & - & 1 & ro \\
\hline & & $\begin{array}{l}\text { Oxen yokes were abandoned, } \\
\text { whose rent was paid with } \\
\text { Delgado landrace }\end{array}$ & 1 & d & - & - \\
\hline & Affecting maize & $\begin{array}{l}\text { Other crops gained popular- } \\
\text { ity }\end{array}$ & & & & \\
\hline & & Tomato & 2 & $\mathrm{~d}, \mathrm{n}$ & 1 & an \\
\hline & & Fruit crops & 1 & $\mathrm{cu}, \mathrm{n}$ & 3 & $\mathrm{cr}, \mathrm{n}$ \\
\hline & & Nopal & 1 & an, d, dm & 4 & an, d, dm \\
\hline & & Sorghum & 1 & an, $\mathrm{d}, \mathrm{n}, \mathrm{ro}, \mathrm{t}$ & 2 & an \\
\hline & & Rice & - & - & 1 & an \\
\hline & & Sugar cane & - & - & 1 & d \\
\hline
\end{tabular}


Table 4 (continued)

\begin{tabular}{|c|c|c|c|c|c|c|}
\hline \multicolumn{2}{|c|}{ Changes in multilevel perspective } & \multirow{3}{*}{$\begin{array}{l}\text { Farmers' explanations } \\
\text { Farmers who adopt hybrids } \\
\text { were perceived as innova- } \\
\text { tive }\end{array}$} & \multicolumn{2}{|c|}{ Focus groups (19) } & \multicolumn{2}{|c|}{ Interviews (56) } \\
\hline & & & Freq. & Landraces & Freq. & Landraces \\
\hline \multirow[t]{5}{*}{ Cultural regime } & Affecting landraces & & 2 & an, cu, d, i, n, ro, t & 1 & $\mathrm{cr}$ \\
\hline & & $\begin{array}{l}\text { Aging farmers abandoned the } \\
\text { cultivation of distant plots }\end{array}$ & 2 & $\mathrm{cr}, \mathrm{dm}$ & 2 & $\mathrm{dm}$ \\
\hline & Affecting maize & $\begin{array}{l}\text { Fewer descendants and field } \\
\text { workers were interested in } \\
\text { agriculture }\end{array}$ & 3 & an, am, ar, cr, cu, d, n, t & 5 & an, cr, n, t \\
\hline & $\begin{array}{l}\text { Affecting landraces and/or } \\
\text { maize }\end{array}$ & $\begin{array}{l}\text { Farmer-donor retirement or } \\
\text { death }\end{array}$ & - & - & 13 & an, cu, cr, d, i, n \\
\hline & & $\begin{array}{l}\text { Interviewee was working out } \\
\text { of town }\end{array}$ & - & - & 4 & an, $d$, ro \\
\hline \multirow[t]{3}{*}{ Policy regime } & Affecting landraces & $\begin{array}{l}\text { Subsidies for hybrids coupled } \\
\text { with agricultural extension }\end{array}$ & 2 & an, $\mathrm{d}, \mathrm{n}, \mathrm{ro}, \mathrm{t}$ & 12 & an, $\mathrm{d}, \mathrm{n}, \mathrm{t}$ \\
\hline & Affecting maize & Ejido certification program & 1 & d & - & - \\
\hline & & $\begin{array}{l}\text { Irrigation project in Tetela } \\
\text { del Volcán }\end{array}$ & 1 & $\mathrm{cu}, \mathrm{n}$ & - & - \\
\hline \multirow[t]{2}{*}{ Macro level } & Affecting landraces & $\begin{array}{l}\text { Farmers observed that dry } \\
\text { spells' frequency increased, } \\
\text { preferring hybrids }\end{array}$ & 2 & an, $\mathrm{d}, \mathrm{n}, \mathrm{ro}, \mathrm{t}$ & 5 & an, $d, n$, ro \\
\hline & Affecting maize & $\begin{array}{l}\text { Population increase, urbani- } \\
\text { zation, industrialization }\end{array}$ & 2 & an, $\mathrm{d}, \mathrm{n}$ & 6 & an, $\mathrm{n}$ \\
\hline \multirow[t]{6}{*}{ Other explanations } & & $\begin{array}{l}\text { Plots sold, rented or trans- } \\
\text { ferred due to owner's aging, } \\
\text { sickness or to avoid family } \\
\text { conflict }\end{array}$ & - & - & 4 & an, $\mathrm{d}, \mathrm{t}$ \\
\hline & & $\begin{array}{l}\text { Seed lot lost to pests during } \\
\text { storage }\end{array}$ & - & - & 2 & $\mathrm{~d}, \mathrm{n}$ \\
\hline & & $\begin{array}{l}\text { Introduced a different seed } \\
\text { lot of the same landrace } \\
\text { from relative or market }\end{array}$ & - & - & 2 & an \\
\hline & & $\begin{array}{l}\text { Introduced a different } \\
\text { landrace more resistant to } \\
\text { pests and with better husk }\end{array}$ & - & - & 1 & an \\
\hline & & $\begin{array}{l}\text { Introduced hybrids following } \\
\text { the advice of landowners }\end{array}$ & - & - & 1 & an \\
\hline & & $\begin{array}{l}\text { Farmer-donor introduced } \\
\text { hybrids but interviewee } \\
\text { cannot recall / does not } \\
\text { know why }\end{array}$ & - & - & 4 & an, cr, d, t \\
\hline
\end{tabular}

For a disaggregated version of this table by municipalities see Online Resource 5. Some Multilevel Perspectives categories, such as the infrastructure regime and the niche (micro) level, did not emerge among farmers' responses. Columns show the frequency each explanation was mentioned during interviews and focus groups. Sums of column frequencies do not correspond with the number of interviews or focus groups. Interviewees and focus group participants often provided multiple explanations to abandon one seed lot/landrace. Alternatively, a single cause could explain a reduction in the cultivation of multiple seed lots/landraces

Landraces definitions: am Amarillo, an Ancho, ar Arrocillo, $c r$ Criollo, $c u$ Cuarenteño, $d$ Delgado, $d m$ Del Monte, $i$ Itizihuine, $n$ Negro, $r$ Rojo, $t$ Tehuacán

In three focus groups, the fact that landraces were not adapted to the new cultivation system was considered to be a cause for their abandonment (Table 4). Farmers observed that the substitution of mechanical weeding with chemical treatments increased lodging in landraces. Landraces in Morelos can reach up to $4 \mathrm{~m}$ high. The mounding up of soil at the base of the plants as part of mechanical weeding provided some necessary stability to landraces, but the denser planting arrangement recommended for hybrids complicated mechanical weeding. Farmers found that single-seed sowing meant less support for individual plants and that the recommended chemical fertilization overstimulated the 
production of green matter in landraces. This led to taller plants, further aggravating lodging. For farmers who abandoned animal traction, the height of the landraces became a problem: tractor implements would break the maize plants when they entered the field for the second weeding. Farmers who adopted the new practices often found it too costly or complicated to manage two cultivation systems simultaneously and, consequently, abandoned their landraces.

Farmers in one focus group and three interviewees observed that the more intensive cultivation system caused a reduction of natural soil fertility over the long term (Table 4). These farmers recalled that when they started applying chemical fertilizers they used a small dose per plant that was the volume of a bottle cap. However, they observed that a successful harvest now depended on a higher recommended fertilizer dose. These farmers noticed diminishing yields over time in their landraces as a result of poor soil fertility, and eventually abandoned these landraces.

\section{Climatic macro-level changes favoring hybrids}

A macro-level change in precipitation patterns reinforced the adoption of hybrids for farmers in two groups and in five interviews (Table 4). Farmers perceived that rains were abundant and regular some decades ago, while now they were scarce and erratically distributed. They recalled severe droughts around 1974 and 1982 consistently across municipalities. Farmers recalled losing most of their harvest those years, having to resort to the yellow maize that was brought to the community for consumption, instead of white maize. Based on these observations, farmers preferred hybrids because they found them to be more resistant to dry spells and drought than landraces.

\section{Macro-level urbanization and market regime changes favoring hybrids}

Macro-level population growth and the resulting urbanization fostered the emergence and consolidation of large urban markets. Farmers from Cuernavaca noticed a rapid expansion of the urbanized area after victims of the 1985 Mexico City earthquake relocated to Morelos. The urban population required a larger maize grain market, as maize is the primary staple in the Mexican diet. Within this market a sector specialized in tortilla production, both hand- and machinemade, emerged. Farmers recalled how around the 1960s every household in town was still cultivating and grinding its own maize and making tortillas. Eventually town mills emerged where people could grind maize to make tortillas at home. Later, tortillerías emerged that would sell the final product. Some focus groups recalled the first tortillerías in the 1990s, while others since the 1970s.
Market regime changes had two simultaneous and converging effects on farmers' families. As producers, farmers' focus shifted from satisfying household needs and selling surpluses to neighbors, to satisfying market requirements. As consumers, farmers found in tortillerías a convenient alternative that reduced women's workload. More urban households also meant more maize consumption, but this was in the form of manufactured tortillas. Thus, the characteristics favored by tortilla manufacturers became more important than the consumption characteristics in which landraces outperformed hybrids. Farmers referred to these changes repeatedly (eight times in the groups and six in the interviews, Table 4), explaining that hybrids were more marketable than landraces, that buyers preferred hybrids or that farmers often resorted to manufactured tortillas, even though they consistently stated that landraces made tastier, sweeter and softer tortillas.

These transformations correspond not only to changes in user practices within grain markets but also to changes in the technological regime of grain processing. Tortilla manufacturers noticed that hybrids outperformed some landraces in terms of kilograms of dough and/or number of tortillas per kilogram of grain processed. Consequently, they started specifically demanding hybrids. Industrial maize processing also required grain hardness and size characteristics that hybrids satisfied better. In addition, while neighbors used to buy maize by volume, grain markets started buying maize by weight. The importance of yield by weight, a trait in which hybrids outperformed landraces, increased as a result.

Hybrid maize adoption spread in other parts of Mexico as well. In the northern states, hybrid adoption was widespread and achieved economies of scale (Donnet et al. 2012). Soon farmers from Morelos had to compete with hybrid maize coming from other states at lower prices. The Morelos road infrastructure network, well developed since the 1970s as an entry/exit point to/from Mexico City, facilitated this process (SPP 1981; INEGI 2016). With lower prices and a more competitive market, farmers in two groups and four interviewees expressed that it was no longer possible for them to offset the labor cost to produce landraces or even maize. In one focus group, farmers directly referred to the interstate competition (Table 4).

An urban market for fresh corn-on-the cob (elotes) developed in parallel with the grain market. This was apparent in the emergence of fresh corn-on-the-cob stands as a popular form of street food. Farmers who could access irrigation found this market attractive because fresh cobs could be sold by the ear, instead of by weight or volume. By 2008 more than 2/3 of the 9044 irrigated maize hectares in Morelos were harvested as fresh cobs (INIFAP 2017). Stand owners demanded compact tight-rowed ears that require fewer ingredients to season traditionally, in addition to a yearround supply. Breeders satisfied this demand by developing 
specific fresh corn-on-the-cob hybrids. Farmers in three groups and two interviews explained that middlemen often requested them to grow these hybrids to guarantee the purchase, making hybrid adoption obligatory (Table 4).

\section{Macro-level and market regime changes favoring Ancho}

At the macro level, population increase and urbanization fostered another important market regime change: the development of a market for Ancho. Ancho landrace has characteristic wide, starchy kernels that pop when boiled. Buyers offer a premium price for Ancho because it is used in pozole: a hominy, meat and chili pepper soup. The popularity of pozole for celebrations in Mexican households has given this market considerable potential. Price premiums increased with the development of a size-based seed classification system, embryo removal methods to facilitate popping and a precooked maize processing industry. Demand increased with the development of other industrial applications for the grains' high starch content. Pest incidence limits the production of such high starch grains in warm areas (Romero, F. J., personal communication, September 12, 2017). These factors together favored the production of Ancho landrace in temperate areas with optimum growing conditions. This might explain the observed conservation of Ancho accessions (Table 2) showing a clear non-random distribution in the municipalities of Totolapan, Tlayacapan, Yecapixtla and Atlatlahucan. For three groups and six interviewees the preference for Ancho limited hybrid adoption but also limited the conservation of other landraces over which Ancho was preferred (Table 4).

\section{Policy and cultural regime changes favoring hybrids}

Changes in two other regimes, political and cultural, further reinforced hybrid adoption. Two groups and 12 interviewees highlighted a policy change: the implementation of subsidies for hybrid seeds (Table 4). As part of the national strategy for maize self-sufficiency, the Secretary of Agriculture has allocated resources to support hybrid adoption through state governments. In Morelos these subsidies benefited 871 maize producers with inputs for one to three hectares each in 2017 alone (SAGARPA 2017). Farmers mentioned they became interested in hybrids after receiving financial subsidies or technological packages from government authorities. Additionally, some of these subsidies were linked to transformations in other sectors. In Yautepec farmers recalled that hybrids were promoted in the 1990s through a program coordinating a transition from sugar cane to maize after the closure of the Oacalco sugar mill.

The way farmers perceived maize hybrids changed their cultural regime and encouraged hybrid adoption over landraces. A positive connotation has been embedded in the language used by breeders and the government surrounding the notions of improved varieties and strategies for agricultural modernization. Farmers in two focus groups stated that because they perceived themselves as innovative they were interested in adopting hybrids (Table 4). An interviewee who adopted hybrids expressed that he still perceived people cultivating landraces and using traditional cultivation methods as outdated. Thus the positive associations of hybrids with modernization and forward thinking favored the abandonment of landraces in these cases.

\section{User practice changes affecting specific landraces}

Changes in user practices unrelated to hybrids also affected the cultivation of certain landraces. In Puente de Ixtla farmers used to cultivate Delgado because of its high yield by volume. They preferred this landrace to produce the eight sacks of maize required to pay for the rent of an oxen yoke. In the 1980s Lauro Ortega, one of the most popular governors of Morelos, distributed mules to farmers in the municipality. Farmers abandoned the cultivation of Delgado when they no longer had to pay for the rent for a yoke.

Farmers in one group and one interviewee abandoned black and red landraces (Negro and Rojo) when town mills appeared (Table 4). This happened because some users repeatedly expressed their dissatisfaction when leftover dough of the colored landraces from the previous user would mix with their white dough. Another family abandoned these landraces in order to avoid crosspollination with white landraces in the field when they reduced the area planted with maize. Because buyers prefer white maize for tortillas, grains with mixed colors would have been harder to sell. This represented the loss of valuable germplasm. Farmers in two groups and one interviewee recognized that, while black and red landraces from other states are widely available as grain in the markets, local varieties taste better and are better adapted to local soils and climates.

\section{Alternative markets affecting maize}

The expansion of other agricultural markets affected the cultivation of landraces by reducing the preference for maize cultivation. While investments in irrigation in Morelos supported an increase in the total cultivated surface from 124,564 to 130,345 hectares between 1970 and 2012 (Barseló Oliete 1982; INEGI 2013b), maize cultivation decreased from 50,000 to 35,142 hectares (INIA 1975; INIFAP 2017). Morelos has supplied agricultural products to the vast markets of Mexico City since pre-colonial times (Ávila Sánchez 2002). Whenever the soil and climate in Morelos have proven suitable for highly demanded crops, these have disseminated quickly. Farmers referred to the tomato boom in Atlatlahucan and Totolpan between the 
1960s and 1980s. Government subsidies increased sorghum cultivation for cattle feed since the 1970s in warmer municipalities, including among others Amacuzac, Temixco and Zacualpan. Fruit trees disseminated in Tetela del Volcán since the 1980s after governor Lauro Ortega introduced an irrigation project. Nopal (Opuntia cacti) became popular in Tlalnepantla and Tlayacapan since the 1990s. In these locations crop substitution was the predominant cause for farmers abandoning maize landraces (Table 4).

\section{Macro-level changes affecting maize}

Industrialization was another macro-level process that affected maize cultivation. The remaining agriculture in municipalities of the Cuernavaca Valley was reoriented mostly to peri-urban crops such as vegetables and flowers. This transformation was so strong that maize cultivation had effectively disappeared from the main towns in these municipalities, and we had to relocate our focus groups to smaller towns. Industrialization intensified population growth and urbanization. Farmers in two groups and six interviews explained that they decided to abandon maize when their plots ended up surrounded by urban zones, because passers-by would steal a significant harvest share as fresh cobs (Table 4).

\section{Policy and cultural regimes changes affecting maize}

Land use change was intensified when in 1992 the government modified Article 27 of the Constitution and emitted a New Agrarian Law (SEGOB 1992). Land ownership was previously recognized collectively and ejido membership, land use and land transactions were restricted in favor of the collective interest of ejido members. ${ }^{6}$ Instead, the new law and its operational program PROCEDE favored market efficiency. They opened up the possibility for members to obtain individual plot certificates and sell their plots to agents outside the ejidos (Bouquet 1996). Ejidos could choose to participate in the certification program collectively, upon approval of the general assembly. In the study area, certification favored plot sales and often resulted in urbanization. ${ }^{7}$ Focus group participants in Atlatlahucan explained that tomato growers, unable to repay their credits after bad years, sold their plots to developers or lost them to the bank. Ejidos like Nepopualco in the municipality of Totolapan chose not to participate in PROCEDE to retain

\footnotetext{
${ }^{6}$ In Mexico, population nucleus or legal entity with legal personality and its own patrimony; as well as the lands subject to a special regime of social ownership in land tenure (Procuraduría 2009).

7 Although different outcomes were observed in other ejidos. See for example Nuijten (2003); Reyes Ramos (2008) or Torres-Mazuera (2014)
}

their cohesion. Coincidentally, the three families from Nepopualco who donated Ancho maize in 1967 were cultivating Ancho of the same and different seed lots in 2017.

A cultural change derived from urban transformations further affected maize cultivation. People's interest in agriculture decreased with the possibility of obtaining an urban job. The urban lifestyle was often perceived as superior in rural areas. In three groups and five interviews farmers explained how they struggled to foster enthusiasm for agriculture in their grandchildren (Table 4). Moreover, they explained how it had become difficult to find sufficient seasonal fieldworkers. Fieldworkers were demanding a shorter workday and a compensation of MXN\$200/day (approximately US\$10), which farmers found unreasonably high.

Reduction of the average plot size as a result of land division among descendants also increased the interest in urban jobs. In 1970 there were 8118 ejido members reported for 347,623 hectares of arable land in Morelos (Barseló Oliete 1982). By 2007 ejido surface area increased to 396,526 hectares, but the number of members increased to 64,157 (INEGI 2014). As a result, the average area allocated to each member decreased by $86 \%$, from 43 to six hectares. Whenever they were not interested in agriculture or did not inherit land, farmers' descendants found a permanent nonagricultural occupation. To limit land division, some farmers chose not to transfer land to their daughters. They explained that women were expected to obtain land or income from their husband's side. Often, even the most likely successor had to find a temporary off-farm job until the head farmer of the family retired.

In Tlalnepantla and Totolapan, the absence of a younger generation to take over the plots affected maize landrace cultivation (Table 4). As farmers aged, they abandoned maize cultivation in their most distant plots in the mountains. These plots were harder to cultivate because of their cold and humid conditions. Landraces such as Criollo and Del Monte maize (meaning "from the mountains") were adapted to these plots. They were planted earlier in the year, in February or March, and relied on residual soil moisture until the rains arrived. Older farmers abandoned these landraces either by introducing less labor-intensive crops such as forages, or abandoning the plots altogether.

\section{Resistance against the transition}

Interviewees explained how resistance or barriers against the socio-technical transition manifested within individual families. Family members could disagree on which decisions to take about their landrace. In these cases, they had to wait for specific moments to implement their decisions. Farmers emphasized the importance of these moments among the reasons for landrace abandonment in their families. 


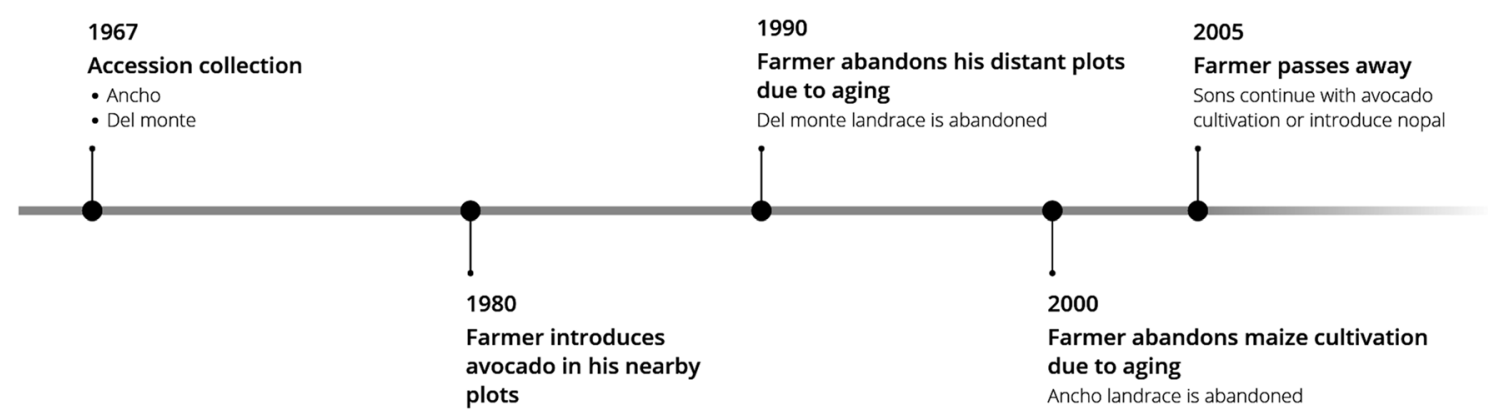

Fig. 4 Timeline for maize landrace abandonment by a family in Tlalnepantla, Tlalnepantla

It was more common for older farmers to resist the change, although we found cases of both generations resisting. In 12 interviews younger farmers wanted to abandon landraces, but older farmers did not. Older farmers manifested their resistance by cultivating their landrace in a small plot until they were no longer able to farm. Young farmers abandoned large-scale landrace cultivation when they took over farm management, and then abandoned landrace cultivation completely when the older farmers passed away (see example in Fig. 4 and details in Online Resource 4, Fig. 1). In four other interviews, older farmers wanted to change their landrace even though their children preferred it (Online Resource 4, Fig. 2). Thus, farmers abandoned their landraces during their children's temporary off-farm occupation. In one interview, landrace abandonment was related to gender dynamics (Online Resource 4, Fig. 3). This young female farmer had to abandon her landrace once she could not take over the labor-intensive cultivation of her father's rocky hillside plots.

In the winter of 2016/2017 we delivered samples from the ex situ collection to interested interviewees and focus group participants. During interviews, 21 families who had lost their seed lots expressed interest in recovering them because of the personal value they attributed to their father, mother or grandfather's seeds. Nine other families wanted to recover their accessions for their productive value. They recalled liking their landrace but had been unable to obtain seeds in the market. All families were surprised to find out that their seeds had been conserved elsewhere and could be retrieved.

\section{Discussion}

Our longitudinal study allowed us to examine in situ conservation from a novel perspective (Ortega-Paczka 1973; Fenzi et al. 2015). For the first time, we interviewed the same group of farmers' families after a 50-year period and systematically collected evidence on how farmers were affected by multiple factors. Photographs of the original collections were fundamental for the study because they allowed us to address the interviewees and focus group participants with a visual reference to their material.

Our actor-centered approach focused on farmers' accounts had both advantages and challenges. In depth interviews allowed us to examine farmers' perspectives and the precise moment when their landrace management decisions took place. But interviewed families were scattered in different environments and cultivated different landraces. This temporal, spatial and landrace heterogeneity brought several dynamics to our attention and also complexity to the analysis. The application of an integrated perspective emerged, in fact, as an a posteriori analytical choice in response to the data.

Applying the MLP allowed us to frame the various causes for maize landrace abandonment together and identify the key drivers of the transition process. Previous studies detected similar causes affecting maize landrace cultivation in Mexico (Ortega-Paczka 1973, 2003; Rice 2007; Bellon and Hellin 2011; Astier et al. 2012; Orozco-Ramírez and Astier 2017). However, the focus of these studies was not on the interaction among these causes. In the municipalities the most common reason for landrace abandonment was the agronomic superiority of the hybrids. However, we found that the preference for hybrids was supported by an entire enabling environment that emerged through the combination of changes in the technological, market, policy and cultural regimes. This enabling environment favored the displacement of landraces by hybrids, other crops, and other economic activities, particularly during the shift from one farmer generation to the next.

We found that urbanization, population growth and industrialization were important indirect factors for landrace abandonment. Brush (1995) and Chambers et al. (2007) similarly reported that these factors affected maize landrace cultivation. It was clear during our search for families in municipalities such as Cuernavaca, Jiutepec, Temixco and Tepoztlán that their urban matrix and demographics have been dramatically transformed during the past 50 years. As a direct cause, these macro-level categories were relatively less important, as the plots of only a handful of families 
were located in areas that have been urbanized. Nevertheless, farmers in our study felt affected by the indirect consequences of these transformations in the market regime via an increased demand for food and in the cultural regime via an increased demand for labor.

Two additional trends not reflected in the aggregated frequencies were notable. The first trend was the occurrence of location-specific causes for landrace abandonment. Temperature and precipitation varying with geography and elevation distinguished the agricultural capacities of the various municipalities. Some areas were more suitable than others for maize, other crops or hybrids. Macro-level forces and local policies further accentuated territorial differences. These differences explained, for example, the popularity of nopal in Tlalnepantla, fruit crops in Tetela del Volcán, and the influence of urbanization in the municipalities close to Cuernavaca. In these locations, such influences were the predominant explanation for landrace abandonment.

The second trend was the occurrence of landrace-specific causes for their abandonment. Market competition with hybrids was more intense for landraces that were best suited for tortilla preparation. This is because a mechanized form of tortilla preparation emerged and became predominant, and landraces were outcompeted by hybrids in this new environment. As a result, landraces such as Pepitilla, Criollo, Del Monte, Itzihuine, Tehuacán, Arrocillo and Amarillo were more likely to be substituted by hybrids.

In contrast, farmers value and prefer some landraces for specific preparations: Ancho maize for pozole, red landraces for pinole and black landraces for atole, fresh corn-on-thecob and special tortillas. These landraces were less likely to have been abandoned during the study period. Moreover, their cultivation increased with the development of specialty markets, as reported by Brush (1995), Bellon (1996) and Hellin and Keleman (2013). Ten of the 13 seed lots introduced by the interviewed families after the 1967 collection belonged to these specialty landraces.

Finally, our findings highlight the value of multi-level analysis to obtain a comprehensive picture of the causes of genetic erosion in situ. The municipalities were important repositories of diversity that had been lost in the families and conserved a considerable larger share of the collection accessions. Nonetheless, maize landrace cultivation has also been decreasing in the municipalities since 1967 . We also observed changes in the landraces' relative frequencies in both families and municipalities. Therefore, ex situ and in situ conservation efforts are still necessary, despite the continued presence of all races found in recent collections in Morelos and elsewhere in Mexico (Arias et al. 2007; CONABIO 2011). These efforts could include the return of genebank materials to interested families, the installation of community seed banks to safeguard the local germplasm for interested young farmers, participatory plant breeding to enhance the agronomic performance of landraces, and the design of industrial processing mechanisms for landraces in coordination with tortilla manufacturers and other maize processors.

\section{Conclusions}

Identifying the causes affecting maize landrace cultivation and how these causes are interrelated helped us understand how reversal forces can be identified and supported. In the same manner that niches were created for hybrids, niches for landrace conservation and even expansion could be supported. The regime changes reviewed indicated that the prevailing rules of the system currently favor maize hybrids. New niches would have to allow landrace cultivation to deviate from the existing rules and encourage farmers and processors to connect with and learn from other actors in the various regimes. This would avoid locked-in situations in which the cultivation of hybrids continues to systematically exclude landraces. These are desirable interventions because the conservation of all maize landraces in situ is of global public interest and service (Vanloqueren and Baret 2009).

Working with actors who are in the best position to influence farmers' choices would provide opportunities to develop these niches. Our findings indicate that these actors could be the intermediate buyers, tortilla manufacturers, other maize processors and urban consumers. In several maize markets, industrial requirements and the preference for low prices have so far overridden consumption preferences. However, exposing these actors to the favorable consumption characteristics of landraces and explaining to them the potential impact of their choices could stimulate their interest in landrace conservation. It would be beneficial to encourage these actors to pay fair market prices that account for the additional labor costs currently needed for landrace production, in exchange for superior flavor. In our study, we observed that successful niche market development was a positive factor that has led to the conservation of the Ancho landrace.

A diversified in situ conservation strategy is necessary to accommodate the diversity of maize landraces. Our analysis showed that even in a small state like Morelos, opportunity costs for maize landrace cultivation vary across landraces and locations. It will be important to develop strategies for the industrial processing and commercialization of landraces jointly with tortilla manufacturers. Landraces mostly used for tortilla production are more vulnerable to competition with hybrids. These landraces could benefit from distinct prices and markets to secure their conservation in situ. Meanwhile, territory-based conservation projects should explicitly acknowledge and address the plethora of local challenges, including the local maize supply and 
consumption patterns, the price of alternative cash crops, the risk of harvest theft around urban areas, changing climate patterns, depleted soils, limited family or hired labor and/or the availability of and access to the local germplasm.

Ultimately, it will be key to encourage maize landrace cultivation in the younger generation of farmers. With the aging and retirement of each subsequent farmer generation the conservation of several seed lots and landraces is at risk. It is essential to improve both the public perception and selfperception of farmers who cultivate landraces, emphasizing the invaluable global public service these farmers provide. Most importantly, we should consider that the current generation of young farmers might be the last one to have a personal connection with some of the diversity that has been lost in the field. Therefore, a family-based rather than farmer-based approach could improve conservation efforts. Complementarily, ex situ accessions represent valuable resources for young farmers interested in reversing some of the observed changes. Tapping into the conservation potential of the current farmer generation is an opportunity we should not miss.

Acknowledgements This paper is dedicated to Dr. Takeo Ángel Kato-Yamakake, Associate Professor at the Colegio de Postgraduados (COLPOS). His outstanding attention to detail during his first collection mission, systematically documenting each accession, made this longitudinal study possible. We thank Dr. Rafael Ortega Paczka, José Francisco Romero Portillo, Claudia Vázquez, Ron Sawyer and CIMMYT Maize Genebank staff for their support in different stages of this study. Funding for this research was provided by the CGIAR Research Program on MAIZE Agrifood Systems (CRP-MAIZE AFS) through the International Maize and Wheat Improvement Center (CIMMYT), as well as by the Knowledge, Technology and Innovation Group from Wageningen University and the Institute of Life Sciences from Scuola Superiore Sant'Anna within the Doctoral Program in Agrobiodiversity. The CRP-MAIZE AFS receives support from the Governments of Australia, Belgium, Canada, China, France, India, Japan, Korea, Mexico, Netherlands, New Zealand, Norway, Sweden, Switzerland, U.K., USA, and the World Bank. A special acknowledgement to the families, focus group participants and municipal authorities from Morelos who kindly devoted time to share their experiences with us, on the challenges and rewards of maize landrace conservation.

Open Access This article is distributed under the terms of the Creative Commons Attribution 4.0 International License (http://creativeco mmons.org/licenses/by/4.0/), which permits unrestricted use, distribution, and reproduction in any medium, provided you give appropriate credit to the original author(s) and the source, provide a link to the Creative Commons license, and indicate if changes were made.

\section{References}

Anderson, E., and H. C. Cutler. 1942. Races of Zea Mays: I. Their Recognition and Classification. Annals of the Missouri Botanical Garden 29 (2): 69-88
Arias, L. M., L. Latournerie, S. Montiel, and E. Sauri. 2007. Cambios recientes en la diversidad de maíces criollos de Yucatán, México. Universidad y Ciencia 23 (1): 69-73.

Astier, M., E. Pérez-Agiz, Q. Orozco-Ramírez, M. C. Patricio-Chávez, and A. I. Moreno-Calles. 2012. Sistema agrícolas, conocimiento tradicional y agrobiodiversidad: El maíz en la cuenca del Lago de Pátzcuaro. In Conocimiento tradicional, innovación y reapropiación social, eds. A. Argueta, M. Gómez, and J. Navia, 146-172. Mexico: Siglo XXI.

Ávila Sánchez, H. 2001. La agricultura y la industria en la estructuración-territorial de Morelos. Cuernavaca, Morelos: UNAM, Centro Regional de Investigaciones Multidisciplinarias.

Ávila Sánchez, H. 2002. Aspectos históricos de la formación de regiones en el estado de Morelos (desde sus orígenes hasta 1930). Cuernavaca, Morelos: UNAM, Centro Regional de Investigaciones Multidisciplinarias.

Barseló Oliete, M. T. 1982. Las actividades primarias en el estado de Morelos, 1950-1970. Investigaciones geográficas (12): 67-117.

Bellon, M. R. 1991. The ethnoecology of maize variety management: A case study from Mexico. Human Ecology 19 (3): 389-418.

Bellon, M. R. 1996. The dynamics of crop infraspecific diversity: A conceptual framework at the farmer level 1. Economic Botany 50 (1): 26-39.

Bellon, M. R. 2004. Conceptualizing interventions to support onfarm genetic resource conservation. World Development 32 (1): 159-172.

Bellon, M. R., and S. B. Brush. 1994. Keepers of maize in Chiapas, Mexico. Economic Botany 48 (2): 196-209.

Bellon, M. R., and J. Hellin. 2011. Planting hybrids, keeping landraces: Agricultural modernization and tradition among smallscale maize farmers in Chiapas, Mexico. World Development 39 (8): 1434-1443.

Bellon, M. R., and J. E. Taylor. 1993. "Folk" Soil Taxonomy and the Partial Adoption of New Seed Varieties. Economic Development and Cultural Change 41 (4): 763-786.

Bouquet, E. 1996. La tierra ejidal en Mexico: Mercancia u objeto social? Estudios agrarios (5): 79-104.

Brush, S. B. 1995. In situ conservation of landraces in centers of crop diversity. Crop Science 35 (2): 346-354.

Brush, S. B. 2004. Genetic erosion of crop populations in centers of diversity: A Revision. In Farmers' bounty: locating crop diversity in the contemporary world, ed. S. B. Brush, 153-174. New Haven, CT: Yale University Press.

Brush, S. B., and H. R. Perales. 2007. A maize landscape: Ethnicity and agro-biodiversity in Chiapas Mexico. Agriculture, Ecosystems and Environment 121 (3): 211-221.

Brush, S. B., M. R. Bellon, R. J. Hijmans, Q. Orozco, H. R. Ramírez, Perales, and J. van Etten. 2015. Assessing maize genetic erosion. Proceedings of the National Academy of Sciences 112 (1): E1.

Camacho Villa, T. C., N. Maxted, M. Scholten, and B. Ford-Lloyd. 2005. Defining and identifying crop landraces. Plant Genetic Resources: Characterization and Utilization 3 (3): 373-384.

Chambers, K. J., S. B. Brush, M. N. Grote, and P. Gepts. 2007. Describing Maize (Zea mays L.) Landrace Persistence in the Bajío of Mexico: A Survey of 1940s and 1950s Collection Locations. Economic Botany 61 (1): 60-72.

CONABIO. 2011. Resultados de proyectos relativos a la determinación de centros de origen y diversidad genética de maíz en México. Informe de Gestión y Resultados. Primera versión. https ://www.biodiversidad.gob.mx/genes/pdf/proyecto/InformedeG estion_V1.pdf. Accessed 5 June 2015.

Consejería Jurídica del Poder Ejecutivo del Estado de Morelos. 2014. Ley de Protección y Conservación del Maíz Criollo en su Estado Genético para el Estado de Morelos. Periódico Oficial "Tierra y Libertad" 6 (5199): 10-23. 
Consejería Jurídica del Poder Ejecutivo del Estado de Morelos. 2015. Reglamento de la Ley de Protección y Conservación del Maíz Criollo en su Estado Genético para el Estado de Morelos. Periódico Oficial "Tierra y Libertad" Alcance 6 (5335): 10-16.

Donnet, L., D. López, J. Arista, F. Carrión, V. Hernández, and A. González. 2012. El potencial de mercado de semillas mejoradas de maíz en México. Mexico City: Mexico: CIMMYT.

Duvick, D. N. 1996. Plant Breeding, an Evolutionary Concept. Crop Science 36 (3): 539-548.

Dwivedi, S. L., S. Ceccarelli, M. W. Blair, H. D. Upadhyaya, A. K. Are, and R. Ortiz. 2016. Landrace Germplasm for Improving Yield and Abiotic Stress Adaptation. Trends in Plant Science 21 (1): 31-42.

Fenzi, N., D. I. Jarvis, L. M. Arias Reyes, L. Latournerie Moreno, and J. Tuxill. 2015. Longitudinal analysis of maize diversity in Yucatan, Mexico: influence of agro-ecological factors on landraces conservation and modern variety introduction. Plant Genetic Resources: Characterization and Utilization 15 (1): 1-13.

Frankel, O. H. 1950. The development and maintenance of superior genetic stocks. Heredity 4 (1): 89-102.

Frankel, O. H., and E. Bennett. 1970. Genetic Resources in PlantsTheir Exploration and Conservation. Oxford, UK: Blackwell Scientific Publications.

Geels, F. W. 2002. Technological transitions as evolutionary reconfiguration processes: a multi-level perspective and a case-study. Research Policy 31 (8-9): 1257-1274.

Geels, F. W. 2004. From sectoral systems of innovation to socio-technical systems: Insights about dynamics and change from sociology and institutional theory. Research Policy 33 (6-7): 897-920.

Geels, F. W. 2005. The dynamics of transitions in socio-technical systems: A multi-level analysis of the transition pathway from horsedrawn carriages to automobiles (1860-1930). Technology Analysis \& Strategic Management 17 (4): 445-476.

Geels, F. W. 2012. A socio-technical analysis of low-carbon transitions: introducing the multi-level perspective into transport studies. Journal of Transport Geography 24: 471-482.

Grum, M., E. A. Gyasi, C. Osei, and G. Kranjac-Berisavljevic. 2008. Evaluation of best practices for landrace conservation: Farmer evaluation. Rome, Italy: Bioversity International.

Harlan, J. R., and M. L. Martini. 1936. Problems and results in barley breeding. In USDA Yearbook of Agriculture, 303-346. Washington D.C.: Government Printing Office: United States Department of Agriculture.

Hellin, J., and A. Keleman. 2013. Las variedades criollas del maíz, los mercados especializados y las estrategias de vida de los productores. Revista de Agroecología 29 (2): 7-9.

INEGI. 2013a. Marco Geoestadístico 2013 Versión 6.0 (Inventario Nacional de Viviendas 2012). https://www.inegi.org.mx/app/bibli oteca/ficha.html?upc=702825292829. Accessed 3 July 2015.

INEGI. 2013b. Anuario estadístico y geográfico por entidad federativa 2013. Mexico D.F.: INEGI.

INEGI. 2014. Perspectiva estadística Morelos. Junio, 2014. Aguascalientes: INEGI: Aguascalientes.

INEGI. 2016. Anuario estadístico y geográfico por entidad federativa 2016. Mexico D.F.: INEGI.

INEGI. 2017. Anuario estadístico y geográfico de Morelos 2017. Aguascalientes: INEGI: Aguascalientes.

INIA. 1975. Maíz y Sorgo: Recomendaciones para su cultivo en el estado de Morelos. Zacatepec, Morelos: INIA.

INIFAP. 2017. Agenda técnica agrícola Morelos. Ciudad de México: INIFAP.

Kato, T. A. 1967. Informe general sobre las nuevas colecciones de maíz en México. https://hdl.handle.net/10883/19646. Accessed 17 October 2018.
Keleman, A., J. Hellin, and D. Flores. 2013. Diverse varieties and diverse markets: Scale-related Maize "profitability crossover" in the central Mexican Highlands. Human Ecology 41 (5): 683-705.

Louette, D. 1994. Gestion traditionnelle de variétés de maïs dans la réserve de la biosphère Sierra de Manantlan et conservation in situ des ressources génétiques de plantes cultivées. Montpellier: École Nationale Supérieure Agronomique de Montpellier: These de Doctorat.

Nuijten, M. 2003. Family Property and the Limits of Intervention: The Article 27 Reforms and the PROCEDE Programme in Mexico. Development and Change 34 (3): 475-497.

Orozco-Ramírez, Q., and M. Astier. 2017. Socio-economic and environmental changes related to maize richness in Mexico's central highlands. Agriculture and Human Values 34 (2): 377-391.

Ortega-Paczka, R. A. 1973. Variación en maíz y cambios socioeconómicos en Chiapas, México, 1946-1971. Tesis de Maestría, Especialidad Botánica. Chapingo, Estado de México: Escuela Nacional de Agricultura, Colegio de Postgraduados.

Ortega-Paczka, R. A. 2003. La diversidad del maíz en México. In Sin maíz no hay país, eds. G. Esteva, and C. Marielle, 123-154. Mexico D.F.: Dirección General de Culturas Populares e Indígenas.

Perales, H. R., and D. Golicher. 2014. Mapping the diversity of maize races in Mexico. PLoS ONE 9 (12): e114657.

Perales, H. R., S. B. Brush, and C. O. Qualset. 1998. Agronomic and economic competitiveness of maize landraces and in situ conservation in Mexico. In farmers, gene canks and crop breeding: economic analyses of diversity in wheat, maize, and rice, ed. M. Smale, 109-125. Boston, MA: Kluwer Academic Publishers.

Perales, H. R., S. B. Brush, and C. O. Qualset. 2003a. Dynamic management of maize landraces in Central Mexico. Economic Botany 57 (1): 21-34.

Perales, H. R., S. B. Brush, and C. O. Qualset. 2003b. Landraces of maize in Central Mexico: An altitudinal transect. Economic Botany 57 (1): 7-20.

Pichardo González, B. 2006. La Revolución Verde en México. Agraria 4: 40-68.

Pistorius, R. 1997. Scientists, plants and politics: A history of the plant genetic resources movement. Rome, Italy: IPGRI.

Procuraduría, Agraria. 2009. Glosario de términos juridico-agrarios. Mexico, D.F.: Procuraduría Agraria.

Reyes Ramos, M. E. 2008. La oposición al PROCEDE en Chiapas: Un análisis regional. El Cotidiano 23 (147): 5-19.

Rice, E. 2007. Conservation in a changing world: In situ conservation of the giant maize of Jala. Genetic Resources and Crop Evolution 54 (4): 701-713.

SAGARPA. 2017. Componente: Programa de Incentivos para Productores de Maíz y Frijol "PIMAF" 2017. https://www.gob.mx/ cms/uploads/attachment/file/242989/PUBLICACI_N_6_MOREL OS.pdf. Accessed 20 July 2018.

SEGOB. 1992. DECRETO por el que se reforma el artículo 27 de la Constitución Política de los Estados Unidos Mexicanos. Diario Oficial de la Federación. 6 January 1992 CDLX(3): 2-5.

Smale, M., M. R. Bellon, D. Jarvis, and B. Sthapit. 2004. Economic concepts for designing policies to conserve crop genetic resources on farms. Genetic Resources and Crop Evolution 51 (2): 121-135.

Smith, A. 2007. Translating sustainabilities between green niches and socio-technical regimes. Technology Analysis \& Strategic Management 19 (4): 427-450.

SPP. 1981. Síntesis Geográfica de Morelos. Mexico, D.F: SPP.

Torres-Mazuera, G. 2014. Formas cotidianas de participación política rural: El Procede en Yucatán. Estudios Sociológicos 32 (95): 295-322.

Urquijo, P. S., and G. Bocco. 2011. Los estudios de paisaje y su importancia en México, 1970-2010. Journal of Latin American Geography 2011 (10): 37-63. 
van Heerwaarden, J., F. A. van Eeuwijk, and J. Ross-Ibarra. 2010. Genetic diversity in a crop metapopulation. Heredity 104 (1): 28-39.

van de Wouw, M., C. Kik, T. van Hintum, R. van Treuren, and B. Visser. 2009. Genetic erosion in crops: Concept, research results and challenges. Plant Genetic Resources: Characterization and Utilization 8 (1): 1-15.

Vanloqueren, G., and P. V. Baret. 2009. How agricultural research systems shape a technological regime that develops genetic engineering but locks out agroecological innovations. Food Sovereignty, Agroecology and Biocultural Diversity: Constructing and Contesting Knowledge 38 (6): 971-983.

Verbong, G., and F. W. Geels. 2007. The ongoing energy transition: Lessons from a socio-technical, multi-level analysis of the Dutch electricity system (1960-2004). Energy Policy 35 (2): 1025-1037.

Wale, E. 2012. Explaining farmers' decisions to abandon traditional varieties of crops: Empirical results from Ethiopia and implications for on-farm conservation. Journal of Sustainable Agriculture 36 (5): 545-563.

Wellhausen, E. J., L. M. Roberts, E. Hernández, Xolocotzi, and P. C. Mangelsdorf. 1951. Razas de Maíz en México, su origen, características y distribución. Mexico, D.F.: Secretaria de Agricultura y Ganaderia y Fundacion Rockefeller.

Publisher's Note Springer Nature remains neutral with regard to jurisdictional claims in published maps and institutional affiliations.

Francis Denisse McLean-Rodríguez is a doctoral student in Agrobiodiversity at the Institute of Life Sciences from the Scuola Superiore Sant'Anna in Pisa, Italy. Her research focuses on traditional agrobiodiversity conservation, with a special interest in bringing together socioeconomic, agronomic and genetic approaches. She is currently working on a comparison of in situ and ex situ maize landrace conservation in the state of Morelos, Mexico.

Tania Carolina Camacho-Villa has a multidisciplinary background in Agronomy, Genetic Resources Conservation and Utilization, as well as in Sociology of Rural Development. She has been studying traditional farming systems and technological changes on agriculture. Currently, she is an Associate Scientist at the International Maize and Wheat Improvement Center (CIMMYT) in State of Mexico, Mexico, working on issues related to agricultural innovations and social inclusion.

Conny J. M. Almekinders is an Associate Professor from the Knowledge, Technology and Innovation Group in the Department of Social Sciences of Wageningen University, The Netherlands. She is a professor in the Masters Program in Development and Rural Innovation. Her current research focus is on agricultural technology development, with a special interest in the relationship between technical and social change, and how these play out in socially differentiated rural communities.

Mario Enrico Pè is the Dean of Sciences at the Scuola Superiore Sant'Anna in Pisa, Italy. He is Full Professor of Plant Genetics. His research focuses on quantitative genetics of maize and on the characterization of plant genetic resources, with a special attention to smallholder agriculture in the centers of origins of cereals.

Matteo Dell'Acqua is Assistant Professor at the Institute of Life Sciences from the Scuola Superiore Sant'Anna in Pisa, Italy. He received a $\mathrm{PhD}$ in Agrobiodiversity at the same institution. His research focuses on the interconnection between molecular diversity of plant genetic resources and farmers' traditional knowledge in smallholder farming settings.

Denise E. Costich is the director of the Maize Germplasm Bank of the International Maize and Wheat Improvement Center (CIMMYT) in State of Mexico, Mexico. Her current research focuses on saving maize landraces via community participation and on Dry Chain technology and its implementation in germplasm banks from the largest (international banks) to the smallest (community seed reserves). 